Pathologische Zellbestandteile des roten Blutbildes wurden sequestriert. Die Kontrolle immunkompetenter, lymphatischer Subpopulationen zeigte eine abnorme Funktion der Suppressor-T-Zellen. Möglicherweise besteht ein Zusammenhang mit der Unfähigkeit unserer Patienten, langfristig Antikörper auf Pneumokokkenantigene $\mathrm{zu}$ bilden.

Schlïsselwörter: Milz - Autotransplantation - Suppressor-T-Zellen - Pneumokokkenantigene.

\title{
224. Zur Technik der klinischen segmentalen Pankreastransplantation: Ist die Occlusionsmethode sinnvoll?
}

\author{
W. Land, R. Landgraf, W.-D. Illner, M. Gokel und U. Büll \\ Transplantationszentrum München, Chirurgische Klinik, Klinikum Großhadern, Universität München, \\ Marchioninistraße 15, D-8000 München 70
}

Technique of Clinical Segmental Pancreatic Allografting: Is the Occlusion Method Worthwile to Perform?

\begin{abstract}
Summary. Twelve consecutive segmental pancreatic allografts have been performed in 11 patients using the technique of duct obstruction with Ethibloc in all cases. Five pancreatic allografts are currently functioning (2 years, 1 year, 3 months, 2 months, 1.5 months). There is no evidence (neither by clinical observations, nor by scan or histological studies) that a pancreatic allograft failed due to secondary fibrosis. Thus, we will continue to use the technique of Ethibloc occlusion in clinical pancreatic transplantation.
\end{abstract}

Key words: Duct occlusion - Pancreatic allografting.

Zusammenfassung. Bisher wurden 12 konsekutive segmentale Pankreastransplantationen bei 11 Patienten durchgeführt, wobei in allen Fällen die Gangocclusion mit Ethibloc angewandt wurde. 5 Pankreastransplantate funktionieren derzeit: 2 Jahre, $1 \mathrm{Jahr}, 3$ Monate, 2 Monate, 1,5 Monate. Bisher haben wir keinen Hinweis dafür (weder klinisch noch nuklear-medizinisch noch histologisch), daß ein Pankreastransplantat aufgrund einer sekundär induzierten Pankreasfibrose versagte. Wir sehen daher keinen Grund, die Technik der Gangocclusion mit Ethibloc bei der klinischen Pankreastransplantation im Augenblick zu verlassen.

Schlüsselwörter: Gangocclusion - Pankreastransplantation.

\section{Abhängigkeit der postoperativen Transplantatfunktion von der Operationstechnik bei orthotoper Lebertransplantation}

\author{
Ch. E. Brölsch, P. Neuhaus, H. Creutzig und R. Pichlmayr \\ Klinik für Abdominal- und Transplantationschirurgie der Medizinischen Hochschule Hannover, \\ Konstanty-Gutschow-Straße 8, D-3000 Hannover 61
}

\section{Liver Allograft Function and Its Dependence on the Surgical Technique}

Summary. Orthotopic liver transplantation is carried out in tumor patients and patients with end-stage cirrhosis, whereby different patterns of hepatic circulation are found. In cirrhotics total blood supply is diminished due to excessive collateralisation. Therefore, the hepatic arterial supply becomes significant for total graft perfusion. The simultaneous connection of the portal vein and the hepatic artery during transplantation leads to improved graft perfusion and reduction of cellular damage, whereby differentiation of circulatory and immunological disturbances is possible.

Key words: Liver transplantation - Graft perfusion - Surgical technique.

Zusammenfassung. Orthotope Lebertransplantationen werden bei Tumor- und Cirrhosepatienten durchgeführt, bei denen hämodynamisch unterschiedliche Ausgangssituationen bestehen. Dieses wirkt sich auf die Tranplantatdurchblutung und -funktion derart aus, da 3 Cirrhosepatienten in Folge der bestehenden Collateralisation eine schlechtere portale Durchblutung haben als Tumorpatienten. Der arteriellen Versorgung kommt deshalb eine besondere Bedeutung zu. Durch gleichzeitigen Anschluß von Pfortader und Leberarterie kommt es zu einer optimalen Perfusion und Reduktion des cellulären Schadens.

Schlüsselwörter: Lebertransplantation - Transplantatperfusion - Operationstechnik. 